\title{
Legislative Vehicles and Formalized Charter Review
}

\author{
Charlie Feldman*
}

\section{Introduction}

When and how does the Parliament of Canada examine proposed legislation for its compliance with the Canadian Charter of Rights and Freedoms? ${ }^{1}$ While the Federal Court has observed that - with respect to legislation - "Parliament plays a crucial examination role in identifying inconsistencies with guaranteed rights," ${ }^{2}$ Parliament cannot be said to have adopted formal obligations in this regard. ${ }^{3}$

Although parliamentarians consider the constitutionality of proposed legislation through various means, formalized review occurs only with respect to specific classes of legislation and does not mirror how courts review impugned legislation. This article compares and contrasts current parliamentary practices aimed at Charter compliance and explains where gaps exist.

\section{Legislative vehicles and formalized Charter review}

\section{Overview}

Legislation before Parliament is divided between public bills and private bills. Public bills are statutes of general application and are considered frequently; private bills are increasingly rare and generally involve a specific individual or entity. Both the Senate and House of Commons further categorize public bills based on their provenance. In the Senate, public bills are either Government Bills (those on behalf of Cabinet) or Senate Pub- lic Bills. ${ }^{5}$ Similarly, in the House of Commons, public bills are either Government Bills (those introduced by Members of Cabinet) or Private Members' Bills (those introduced by Members not in Cabinet). ${ }^{6}$ For clarity, Private Members' Bills in the House of Commons are akin to Senate Public Bills in the Senate, and both are public bills. ${ }^{7}$ Although the types of legislation are essentially the same in each chamber (government bill, other public bill, private bill), the constitution requires certain legislative matters to be introduced in the House. ${ }^{8}$

While the frequency with which each type of legislation is proposed and passed differs significantly and varies over time, ${ }^{9}$ each of these six legislative vehicles produces enactments subject to Charter scrutiny. As such, this paper will review each type of legislation in turn, examining its formalized Charter compliance scheme. Formalization in this context refers to instances where statutes, the Senate Rules, or the Standing Orders of the House of Commons specifically provide for the review of a bill's constitutionality. Such formalization is significant in part because it reflects recognition by the legislature of Parliament's role in ensuring Charter compliance.

Although this article focuses on formalized means of Charter review, it must be acknowledged that MPs and Senators engage with the Charter informally through various means, including, for example, by raising concerns about constitutionality during debate or asking a committee witness for a legal opinion in this regard. While such exchanges may inform parliamentarians' 
understanding of the legislation before them, these processes are informal because no parliamentarian is required to consider or raise issues of constitutionality at any point during chamber debate or committee consideration. As well, hybrid processes related to Charter compliance also exist in circumstances where parliamentarians might, for example, place written questions on the Order Paper or present petitions related to the constitutionality of legislation. These processes are informal insofar as there is no requirement to place Charter-related queries through these means; however, these processes are formal to the extent that they may obligate the government to respond in some way. ${ }^{10}$

\section{Government bills introduced in the House of Commons}

The Charter review of government bills introduced in the House of Commons is provided by subsection 4.1(1) of the Department of Justice Act, which requires the Minister of Justice to examine all bills introduced or presented to the House of Commons by a Minister and report to the House when there are provisions that are "inconsistent" with the Charter. ${ }^{11}$ The actual review of legislation pursuant to this provision is conducted by counsel at the Department of Justice. ${ }^{12}$

No such report of Charter inconsistency has ever been tabled in Parliament; however, over fifty provisions of various federal statutes have been invalidated by the Supreme Court of Canada for violating the Charter. ${ }^{13}$ As a result, academics have questioned the effectiveness of subsection 4.1(1) in informing Parliament so as to ensure its enactments are constitutionally sound. ${ }^{14}$ Importantly, section 4.1 review may play an important role in the development of legislation prior to its introduction in Parliament so as to mitigate any Charter concerns in the legislative proposal Parliament ultimately receives. ${ }^{15}$ However, conducting a review and addressing concerns does not mean that all such concerns are eliminated. Indeed, as the Department of Justice itself notes, "While a proposal may not be 'reportable', it may present serious Charter risks." 16

A recent legal challenge questioned the Department of Justice's approach to this provi- sion whereby inconsistency between a bill and the Charter is to be reported to the House only when there is no "credible argument" in support of the measure. As Justice Noel of the Federal Court remarked, "[T] here is no doubt the reporting mechanism is weak [...]. If the objective of the examination provisions was to guarantee that laws do not breach guaranteed rights, then the legislation needs to be reworded." ${ }^{17}$

Essentially this reporting standard means that the government only informs Parliament that its legislation is inconsistent with the Charter if no argument exists at the tail end of the section 1 justification to support the measure at the time of its introduction. In other words, Parliament is not informed if a measure infringes Charter rights but does not violate them, or if there is infringement and the section 1 justification is incredibly weak. As long as there is some credible argument that can be advanced in support of a measure, Parliament receives no section 4.1 report.

From a Parliamentary perspective, it may not always be clear that section 4.1 review has occurred. The absence of a report, according to the former Parliamentary Secretary to the Minister of Justice, means "that the Minister had concluded that the government bill was not inconsistent with the Charter." ${ }^{18}$ However, as Access to Information Act requests reveal, the certification of bills is not immediate upon introduction, ${ }^{19}$ which means that there may be a period wherein parliamentarians are potentially unaware that a section 4.1 report might be issued on a matter with which they are seized. As well, parliamentary questions related to reviews appear to be answered inconsistently. For example, one query produced a response that "This Bill is consistent with the purposes and provisions of the Charter," ${ }^{20}$ whereas another asserted solicitor-client privilege and made no such statement regarding consistency. ${ }^{21}$

Section 4.1 review is the only formalized Charter review that government bills introduced in the House receive. As the Speaker of the House has indicated: 
The Chair is not aware of further constitutional compliance tests that are applied to any kind of legislation, whether sponsored by the government or by private members, once bills are before the House or its committees. ${ }^{22}$

As such, amendments to otherwise compliant bills rendering them unconstitutional are not caught by section 4.1 . When bills are amended by the Senate and sent back to the House, a fresh section 4.1 review does not occur because messages between chambers are not subject to section 4.1.

\section{Government bills introduced in the Senate}

No formalized mechanism exists for Charter review of government bills introduced in the Senate. Such bills would be subject to the section 4.1 process discussed above upon their presentation to the House of Commons.

\section{Private Members' Bills introduced in the House of Commons}

Pursuant to the Standing Orders of the House of Commons, bills and motions introduced in the House by Members not in Cabinet must be examined by the Subcommittee on Private Members' Business (SMEM). ${ }^{23}$ This subcommittee determines the bill's votability - essentially, whether the item can be voted on in order that it may continue in the legislative process after Second Reading. ${ }^{24}$ Since 2003, the votability criteria of SMEM includes - among other considerations - the requirement that "Bills and motions must not clearly violate the Constitution Acts, 1867 to 1982, including the Canadian Charter of Rights and Freedoms." 25

Importantly, this criterion does not seek Charter compliance; rather, the standard that a bill "must not clearly violate" the Charter leaves open the possibility of significant infringement. Procedurally, if SMEM determines that a bill is non-votable, the item advances to its parent committee, the Standing Committee on Procedure and House Affairs (PROC) for review. PROC confirms or rejects SMEM's votability determination, and its determination is subject to appeal to the House as a whole, which votes by secret ballot on such matters. ${ }^{26}$
PROC and SMEM's analyses of constitutionality are not legal determinations undertaken by legal actors in a judicial setting where, for example, considerations of due process would apply. The committees are comprised of MPs, some of whom may be lawyers, but this is not a requirement; nor is there is any requirement that they consider matters before them impartially. The standard of "clearly violates" is applied without any formal presentation of opposing arguments, and the conclusion on this point is not separate and discrete from the other votability criteria. Moreover, inherent political considerations exist in the vetting process because the House itself can overturn a SMEM/PROC decision that something remain non-votable.

SMEM's reports are not public. As such, it may be that Members appearing before PROC to challenge SMEM's decision may not know the specific reasons for SMEM's determination of non-votability. ${ }^{27} \mathrm{~A}$ similar issue arises later in the process because PROC reports may not indicate a reason for non-votability. ${ }^{28}$ This might be of concern for the House as a whole when a member seeks to appeal PROC's decision - the basis of which may not be fully known or understood.

Practically, the lack of a public SMEM report coupled with the lack of reasons for PROC's conclusion as to votability allows for speculation as to why a bill was designated non-votable. From a political perspective this is perhaps advantageous as it provides cover for whatever considerations may have fuelled a particular decision. From a legal standpoint, however, this state of affairs provides little means of assessing the extent to which legal considerations proved determinative in the committee's work and fewer means by which to evaluate parliamentarians' understanding of the state of the law. Indeed, it is not possible from the available record to state with certainty that any Private Members' Bill has in fact been designated as non-votable solely on the basis of its unconstitutionality.

To illustrate this process as it plays out, consider Bill C-450 of the 37th Parliament, 3rd Session. This legislation invoked the notwithstanding clause of the Charter to limit recognition of same-sex marriage. ${ }^{29}$ SMEM deemed the 
item non-votable. ${ }^{30}$ PROC confirmed the item as non-votable and it subsequently went to the House for limited debate before being dropped from the Order Paper without a vote. ${ }^{31}$ Because SMEM met in camera - its standard practice at the time - the PROC and House debates are the only indications of parliamentary understanding of the constitutionality of this legislation. Much was said in the debate about same-sex marriage and the reference case then before the Supreme Court; ${ }^{32}$ however, the constitutionality of invoking the notwithstanding clause was raised.

Questions were asked at committee such as: "Are you proposing that the notwithstanding clause be invoked in this instance to counter the Canadian Charter of Rights and Freedoms?" 33 This question suggests that in the mind of the questioner the notwithstanding clause is not itself part of the Charter. Whether one thinks a particular application of the notwithstanding clause is appropriate is a very different question from whether it is constitutional. The ultimate impression one would have from the conclusion of PROC is that the act of invoking the notwithstanding clause of the constitution is itself a clear violation of the constitution. Indeed, it is difficult from the record alone to discern any discrete legal concerns with the legislation as opposed to concerns over the policy choices of the government in respect of same-sex marriage. Again, the lack of any public report indicating specific reason(s) for a votability determination means it cannot be concluded that, in fact, Parliament or a subset of parliamentarians believed the bill was unconstitutional.

SMEM/PROC's votability determination includes the consideration of whether a bill "clearly violates" the constitution, leaving open the question of whether there is a role for these committees in respect of bills that infringe Charter rights - perhaps even significantly - but are just shy of "clear" violation? In SMEM deliberations, one sees references to whether a bill might be "fixable," 33 or whether its provisions "could be [...] amended, or qualified" 35 such that it does not violate the Charter. The suggestion appears to be that a subsequent reviewing body could 'fix' a bill that has a lesser Charter defect identified by
SMEM, presumably through amendment. However, neither SMEM nor PROC has any capacity to ensure follow-up, nor are they seized of the bill in such a way as to amend it if so warranted. Further, neither committee is in a position to require another committee to amend a bill in a certain way. Consequently, with SMEM/PROC acknowledging future consideration by another committee, there exists a real possibility of a 'parliamentary pass the buck' system with respect to ensuring the constitutional compliance of bills introduced as matters of private members' business in the House of Commons. That is, even if the SMEM process flags bills that infringe but do not clearly violate the Charter, there is no mechanism at present that ensures any identified defects are revisited or cured.

As a final note, SMEM's work occurs before a full committee considers a bill. As such, it is possible that amendments made later in the process could render an otherwise compliant bill unconstitutional. Such issues would not be caught by any formalized mechanism of the House or Senate.

\section{Senate public bills}

Senate public bills - public bills initiated by a Senator who is not a minister - are not subject to any formal review process during the Senate's consideration of such legislation.

If a Senate public bill is passed and sponsored by a Member in the House, the bill is sent to SMEM for review. Unlike its review of private members' business introduced in the House of Commons, SMEM reviews Senate public bills through only one criterion: "whether a similar matter has been voted on by the House in the same Parliament." ${ }^{36}$ Thus, Senate public bills are not reviewed for Charter compliance by any formal mechanism at any point in their journey through Parliament.

\section{Private bills}

Private bills are relatively rare in modern parliamentary practice. However, an oft-ignored mechanism relative to the Charter compliance of these bills exists that deserves consideration. 
Specifically, the Supreme Court Act allows for references regarding private bills to originate from the Senate or House of Commons by motion of either chamber. ${ }^{37}$ This reference power also finds expression in Senate Rule 11-18: "At any time before the adoption of a private bill, the Senate may order that it be referred to the Supreme Court of Canada for examination and an opinion on any point identified in the order of reference to the court." 38

This provision has been used thrice, all in the 19th Century. Each case, one from 1876 and two from 1882, concerns a private entity being incorporated by statute. ${ }^{39}$ While these three references pre-date the Canadian Charter of Rights and Freedoms, it would follow that questions regarding the Charter compliance of a private bill could be referred to the Supreme Court by either House of Parliament pursuant to this provision in the Supreme Court Act. ${ }^{40}$

It is perhaps worth considering that the most direct and fulsome means by which Parliament can authoritatively inform itself of a bill's con- stitutionality - namely, by hearing from the Supreme Court directly - can only be accomplished in the context of its least-used legislative vehicle. ${ }^{41}$ Whether this power should be expanded to include other legislation is at Parliament's discretion.

\section{Comparison and design questions}

\section{Charter reviews in Parliament compared}

A comparison of the Charter reviews discussed above is illustrated in the table below.

As the foregoing table and discussion demonstrate, various actors apply different standards of Charter review at different points in the process with varying outputs depending on the legislative vehicle. This formalized review is distinct from any Charter analysis that may occur during the process of drafting legislation. Perhaps most notable is the difference in review between what the Supreme Court might be asked on a private bill reference ${ }^{42}$ and what parliamentarians seek

\begin{tabular}{|c|c|c|c|c|c|}
\hline Item & Process & Reason & Result & $\begin{array}{l}\text { Review } \\
\text { Question }\end{array}$ & Actors \\
\hline $\begin{array}{l}\text { Government } \\
\text { Bill Introduced } \\
\text { in the House }\end{array}$ & $\begin{array}{l}\text { Section } 4.1 \text { review } \\
\text { upon introduction }\end{array}$ & $\begin{array}{l}\text { Statute - } \\
\text { Department } \\
\text { of Justice Act }\end{array}$ & $\begin{array}{l}\text { Report of } \\
\text { Inconsistency }\end{array}$ & $\begin{array}{l}\text { Is there } \\
\text { "inconsistency" } \\
\text { with the } \\
\text { Charter? }\end{array}$ & $\begin{array}{l}\text { Counsel at the } \\
\text { Department of } \\
\text { Justice, Minister of } \\
\text { Justice }\end{array}$ \\
\hline $\begin{array}{l}\text { Government } \\
\text { Bill Introduced } \\
\text { in the Senate }\end{array}$ & $\begin{array}{l}\text { None (Note: section } \\
4.1 \text { review if later } \\
\text { presented to the } \\
\text { House) }\end{array}$ & N/A & None & None & None \\
\hline $\begin{array}{l}\text { Private } \\
\text { Members' Bill } \\
\text { introduced in } \\
\text { the House }\end{array}$ & $\begin{array}{l}\text { SMEM review before } \\
\text { Second Reading }\end{array}$ & $\begin{array}{l}\text { Standing } \\
\text { Orders of } \\
\text { the House of } \\
\text { Commons }\end{array}$ & $\begin{array}{l}\text { Determination } \\
\text { of Non- } \\
\text { votability }\end{array}$ & $\begin{array}{l}\text { Does it "clearly } \\
\text { violate" the } \\
\text { Charter? }\end{array}$ & $\begin{array}{l}\text { MPs on SMEM, } \\
\text { assisted by } \\
\text { Analyst }\end{array}$ \\
\hline $\begin{array}{l}\text { Senate Public } \\
\text { Bill }\end{array}$ & None & N/A & None & None & None \\
\hline Private Bill & $\begin{array}{l}\text { Supreme Court of } \\
\text { Canada Reference (if } \\
\text { desired) }\end{array}$ & $\begin{array}{l}\text { Statute - } \\
\text { Supreme } \\
\text { Court Act } \\
\text { (also in } \\
\text { Senate } \\
\text { Rules) }\end{array}$ & $\begin{array}{l}\text { Decision of } \\
\text { the Supreme } \\
\text { Court of } \\
\text { Canada }\end{array}$ & $\begin{array}{l}\text { Is it } \\
\text { constitutional? } \\
\text { (Senate or } \\
\text { House would } \\
\text { determine the } \\
\text { question(s)) }\end{array}$ & $\begin{array}{l}\text { Two or more } \\
\text { Justices of the } \\
\text { Supreme Court of } \\
\text { Canada }\end{array}$ \\
\hline
\end{tabular}


through SMEM and section 4.1 review. As well, one should remember that unlike their Houseinitiated counterparts, public bills originating in the Senate receive no formalized review.

The formalized practices of Parliament such as those documented above are codified in the Senate Rules and Standing Orders of the House of Commons - which each chamber amends exclusively from time to time - as well as in ordinary statutes, which require the consent of both chambers as well as Royal Assent. The locus of the formalization is of particular importance not only for how a measure comes to be. While either the Senate or House can decide to operate "notwithstanding any Rule" or "notwithstanding any Standing Order or usual practice of the House," a chamber alone cannot set aside a statutory provision.

\section{Questions of design}

The differing standards and processes for Charter review in Parliament suggest a number of design questions may lack consistent answers within the current framework. These questions are explored below.

\section{1) Should all legislation be reviewed?}

Perhaps from a resources perspective it makes sense only to review those measures advancing for debate instead of the hundreds of backbench bills that are destined to die on the Order Paper. However, it is curious that for private members' business that originates in the House there is a concern with Charter compatibility yet bills under this rubric originating in the Senate are not subject to the same House scrutiny. Does this system presume - on the House side that some Senate review has already occurred in this respect? Or, is there some other justification for Senate-introduced measures receiving less review as part of the parliamentary process?

\section{2) Who should review legislation?}

As illustrated by the table above, current procedures involve the consideration of legislation by government lawyers, parliamentarians who may not be lawyers, and possibly justices of the Supreme Court depending on the legisla- tive vehicle. Perhaps it goes without saying that there are advantages and disadvantages to each approach, but it may be that other possibilities exist, such as engaging external independent legal experts.

\section{3) Should review be mandatory or optional?}

There is a great variety of legislation that may be introduced in Parliament and not all of it is suited to Charter review. For example, it may be quite difficult to assess the Charter impact of budgetary policy choices as expressed in appropriations legislation. Similarly, perhaps not all legislation requires review - for example, symbolic legislation designating a new national day or month is unlikely to pose a grave Charter risk. While answering this question carefully may assist in ensuring compliance resources are optimally directed, difficultly would arise in classifying legislation. This would be complicated further if efforts were made by political actors to blur the lines between characterizations of legislation for the purposes of skirting review requirements.

\section{4) By what standard should legislation be reviewed?}

Should all bills be reviewed by the same standard? If so, should it be one concerned with identifying whether there are Charter infringements or whether the infringement is saved by section 1? Perhaps it is preferable to focus Parliament's attention on debating the policy justification of a matter under section 1 only when there is clear infringement instead of, at present, where some parliamentarians may not always grasp the difference between infringement and violation and thus perhaps debate at cross-purposes.

\section{5) When should legislation be reviewed?}

While reviewing legislation upon its introduction is ideal in terms of informing as much of its parliamentary consideration as possible, there is a risk that legislation may be amended in such a way as to render it unconstitutional. However, the time between certain stages of consideration may be limited, and it may not always be possible to advise Parliament on amendments, particularly when these might be moved without notice 
in committee. A system allowing for subsequent reviews when legislation is amended during its journey through the legislative process might warrant consideration.

\section{6) What should the substantive outcome of review be?}

While the section 4.1 regime foresees Parliament being informed of a bill's inconsistency, this does not necessarily indicate to Parliament how the bill might be rendered consistent. Perhaps Parliament should be afforded information about the compliance as opposed to the non-compliance of legislation and this might even include the policy justifications that would be advanced by the government under section 1 if the legislation were challenged. At the same time, a complex legal opinion may not best serve parliamentarians with no legal training - and could present questions as to whether support of a measure ought to be interpreted as a sign that Parliament agrees with the substance of a legal opinion rather than its conclusions.

\section{7) What should the procedural outcome of review be?}

As noted with the case of SMEM, it is possible for Parliament to determine that bills cannot be voted upon in certain circumstances. While this outcome could be applied to a bill identified as unconstitutional, there could be other avenues as well, including means to refer the matter for unique committee consideration of its constitutionality apart from any policy consideration. Alternatively, a process could be devised by which Parliament first has to vote procedurally to consider a measure with identified significant Charter risks prior to being able to vote on its substance.

\section{8) Should there be a responsibility to address identified concerns or oversight to ensure issues are addressed?}

If a system of checks and balances is created with respect to legislative rights compliance, who or what should respond to a report of constitutionality issues, however produced? Will a committee be seized of the matter? Is there an obligation on some actor to verify that efforts at mitigation were made prior to a bill's passage?

\section{9) What timelines should be established, if any?}

Assuming any formalized review is independent of the drafting of legislation, not much time may exist between when the text of a bill becomes public and when Parliament is first seized of the matter. Debate would be best served by knowing the legal risks associated with the enactment; however, Parliament cannot be hampered in its ability to legislate as expediently as it feels appropriate. Rushed review is not ideal, but neither is a scheme under which Parliament is potentially informed of Charter risks only after a measure has the force of law. A delicate balance must be struck in this regard.

\section{0) What process exemptions - if any - should exist?}

The great variety of legislation before Parliament may require considering process exemptions. For example, back-to-work legislation is typically introduced in response to an important on-going situation such that Parliament tends to act within a matter of days, if not hours. ${ }^{43}$ Perhaps it may be appropriate to provide procedural avenues allowing for temporary exemptions to a compliance process in such cases, or creating alternative processes specific to such circumstances.

\section{1) Where should the review process be enshrined?}

The locus of formalization is important given Parliament's inability to avoid a statutory obligation but desire for flexibility in allowing for exemptions from Standing Orders. With respect to remedy for breach, it may be appropriate to mirror obligations in both statute and the Standing Orders to ensure all parliamentary and judicial avenues for enforcement are available.

\section{Conclusion}

Parliament has not formalized for itself an obligation to ascertain the constitutionality of all legislation before it, although it has established some processes in this regard. With respect to 
review mechanisms that are presently in place, Parliament's Charter compliance system reflects design choices that may, in some cases, produce seemingly contradictory consequences. Consider, for example, a bill that violates the Charter as introduced but that could be saved by invoking the notwithstanding clause. As a House government bill, section 4.1 should operate to produce an inconsistency report but the legislation would proceed regardless. As a proposed Private Members' Bill, the absence of the required notwithstanding clause would likely ensure the non-votability of the measure given the "clear violation" standard. Indeed, the government bill could be considered and passed at all stages whereas the equivalent Private Members' Bill would likely never complete Second Reading in the chamber. Should a Charter review system produce such different procedural results for the same bill depending on its provenance?

As noted above, the only authoritative and direct way by which Parliament can assure itself of a bill's constitutionality is through a Supreme Court of Canada reference, which Parliament can only initiate in the case of its least used legislative vehicle, the private bill. Though rare, Parliament has in the past made the coming into force of statutory provisions dependent on a Supreme Court reference confirming their constitutionality. ${ }^{44}$ Though still not placing an obligation on Parliament vis-à-vis legislation before it, it is possible for Parliament to modify the reference power as it sees fit, including by expanding the ability to make references to other Courts or to allow certain other matters to be referred by Parliament directly.

It should be acknowledged that not all Charter matters are black and white. It may be that Parliament could receive conflicting legal advice from experts with respect to a particular bill's constitutionality. As well, in areas with limited or no case law, there exists the possibility for legal challenge regardless of how Parliament chooses to legislate. Further, it is possible that the Supreme Court could overturn a precedent and thereby change the state of the law entirely. Despite these potential challenges, it is difficult to see an argument that Parliament should not attempt to for- mally review all legislation for Charter compliance prior to its passage. At a minimum, such an investigation may produce reports allowing Parliament to focus its attention, such as inquiring whether an infringement can be mitigated or whether a particular infringement might be justified under section 1 . Such focus would not only assist parliamentarians in their consideration of the legislation, but may also aid courts engaged in determinations of legislative intent by providing a more fulsome parliamentary record on such legal considerations.

The Charter applies to all legislation and presumably Parliament has a vested interest in ensuring the validity of its legislative acts. Yet Parliament's design choices with respect to Charter compliance at present raise many questions - chief among them being why all legislation is not somehow formally checked for compliance with the constitution. Though Parliament is not part of - nor designed to mirror - the judicial branch in how it considers matters, legislators ought to be aware how bills before Parliament would likely be considered by courts should an enactment be challenged. By engaging in such inquiries, Parliament may minimize the likelihood that a statutory provision is ultimately invalidated on Charter grounds.

It is ultimately up to Parliament to determine how best to satisfy itself that legislation before it complies with the Canadian Charter of Rights and Freedoms. In that regard, the Standing Committee on Justice and Human Rights recently adopted a motion that calls in part for study of subsection 4.1(1) of the Department of Justice Act. ${ }^{45}$ Importantly, it is useful to recall that this review and reporting requirement does not apply to all legislation.

Similarly, in relation to recent legislation regarding medical assistance in dying, the Department of Justice published a backgrounder that made specific reference to the section 4.1 obligation and included a "non-exhaustive list of potential impacts on the rights and freedoms guaranteed by the Charter [...] to assist in informing the public and parliamentary debate, and consequently to better enable the dialogue between Parliament and the courts." 46 This back- 
grounder was critiqued for its contents; it concluded generally that the legislation "strikes an appropriate balance between the competing rights" but did not provide a specific fulsome section 1 analysis for each right at issue to support this conclusion. ${ }^{47}$

It is unclear what impact this backgrounder had on Parliament's consideration of the legislation, but it is worth considering that an addendum was later released specifically on the Charter compliance of one aspect of the legislation. ${ }^{48}$ Notably, it is on this very aspect of the legislation that a Charter challenge was initiated within days of its receiving Royal Assent. ${ }^{49}$ Whether such Charter impact statements will be released regarding other bills remains to be seen.

Parliamentary practices are not frozen in time, nor are statutes or standing orders. Parliament possesses the ability to create Charter review processes and specify standards of review as it sees fit. Though its "crucial examination role" with respect to legislative rights compliance has been recognized by the Courts, Parliament may wish to consider design questions in this regard to ensure all legislation is formally reviewed for Charter compliance as part of the parliamentary process.

\section{Endnotes}

* Charlie Feldman, B.C.L., LL.B., B.A., LL.M. The views expressed in this paper are the author's own and do not represent those of any employer. This paper is based on the Charlie Feldman, Charter Compliance and the Canadian Parliamentary Process (LLM Thesis, McGill University Faculty of Law, 2015) [unpublished].

1 Canadian Charter of Rights and Freedoms, Part I of the Constitution Act, 1982, being Schedule B to the Canada Act 1982 (UK), 1982, c 11 [Charter].

2 Schmidt v Canada (AG), 2016 FC 269 at para 267 [Schmidt].

3 By contrast, since 1982, the Supreme Court of Canada has "consistently assumed its duty to measure the content of legislation against the guarantees in our Charter designed to protect individual rights and freedoms.": $R v$ Martineau, [1990] 2 SCR 633 at 643, [1990] 6 WWR 97.

4 See Donald Revell, "Private Bills vs Public Bills: A Provincial Perspective" (1985) 8:4 Canadian Parliamentary Rev 15.

5 See generally Senate of Canada, "Legislative Process: Senate Procedural Notes Number 5", (Ottawa: Senate of Canada: July 2013), online: $<$ www.parl.gc.ca/About/senate/proceduralNotes/ pdf/Procedural-Note-5.pdf $>$ This provides a discussion of Senate legislative vehicles. Note that in some materials, Senate Public Bills are called "private senators' / members' bills".

6 Audrey O'Brien \& Marc Bosc, House of Commons Procedure and Practice, 2nd ed (Cowansville: Thomson Reuters, 2009) at Chapter 16: "The Legislative Process."

7 Confusion between these terms is not unique to Canada. A recent committee of the UK House of Commons recommended such bills be renamed "backbench bills" in part to avoid confusion. See UK, House of Commons Procedure Committee, Private Members' Bills: Second Report of Session 2013-14 Volume I (London: The Stationary Office, 2013) at para 85.

8 Constitution Act, 1867 (UK), 30 \& 31 Vict, c 3, s 91, reprinted in RSC 1985, Appendix II, No 5: "Bills for appropriating any Part of the Public Revenue, or for imposing any Tax or Impost, shall originate in the House of Commons."

9 Canada, Library of Parliament, "Table of Legislation Introduced and Passed by Session", (Ottawa: Library of Parliament, 2016), online: <www.lop.parl.gc.ca/ParlInfo/compilations/ houseofcommons/BillSummary.aspx>.

10 See e.g. House of Commons Debates, 41st Parl, 1st Sess, No 103 (30 March 2012) at 6739-6740.

11 Department of Justice Act, RSC 1985, c J-2, s 4.1(1).

12 See Janet Hiebert, Charter Conflicts: What is Parliament's Role? (Montreal: McGill-Queen's University Press, 2002).

13 Janet L. Hiebert \& James B. Kelly, Parliamentary Bills of Rights: The Experiences of New Zealand and the United Kingdom (Cambridge: Cambridge University Press, 2014) at 73 indicates that 45 such statutes were overturned between 1984 and 2012. Between 2013 and the writing of this paper, additional cases include: $R v$ Nur, 2015 SCC 15, [2015] 1 SCR 773 (striking down Criminal Code, RSC 1985, c C-46 [Criminal Code], ss 95(2)(a)(i), 95(2)(a)(ii)); Carter v Canada (Attorney General), 2015 SCC 5, [2015] 1 SCR 331 (invalidating (with suspension) Criminal Code, s 241(b)); Canada (Attorney General) $v$ Whaling, 2014 
SCC 20, [2014] 1 SCR 392 (striking Abolition of Early Parole Act, SC 2011, c 11, s 10(1)); Canada (Attorney General) v Bedford, 2013 SCC 72, [2013] 3 SCR 1101 (invalidating (with suspension) Criminal Code, ss 197(1), 210, 212(1)(j), 213(1) (c)); and $R v$ Smith, 2015 SCC 34 [2015] 2 SCR 602 (declaring Controlled Drugs and Substances Act, SC 1996, c 19, ss 4-5 of no force and effect to the extent that they prohibit a person with a medical authorization from possessing cannabis derivatives for medical purposes); $R v$ SafarzadehMarkhali, 2016 SCC 14, 334 CCC (3d) 1(striking Criminal Code s 719(3.1)); $R$ v Lloyd, 2016 SCC 13, 334 CCC (3d) 20 (striking s 5(3)(a)(i)(D) of the Controlled Drugs and Substances Act).

14 See Jennifer Bond, "Failure to Report: The Manifestly Unconstitutional Nature of the Human Smugglers Act" (2014) 51:2 Osgoode Hall LJ 377 at 425. See also Grant Huscroft, "Reconciling Duty and Discretion: The Attorney General in the Charter Era" (2009) 35:2 Queen's LJ 773.

15 Standing Committee on Justice and Human Rights, "Evidence", 41st Parl, 1st Sess, No 58 (11 February 2013) at 8 (Kerry-Lynne D Findlay) ("[P] roposals are reviewed for Charter and other legal risks throughout the policy development process, up to and including the introduction of legislation. Relevant risks are brought to the attention of senior officials and ministers, and every effort is made to mitigate them.")

16 Schmidt, supra note 2 (Agreed Statement of Facts) at $\mathrm{p} 48, \mathrm{n}$ 4. Note: For consistency, all quoted references to the Charter will be capitalized and italicised in this work, even if this does not appear in the source material.

17 Ibid at para 285-86.

18 Standing Committee on Justice and Human Rights, "Evidence", 41st Parl, 1st Sess, No 59 (13 February 2013) at 15 (Kerry-Lynne D Findlay).

19 See for example, Access to Information Request A-2015-00270 (PCO) and Access to Information Request AI-2015-00010 (PCO). On file with author.

20 Canada, Parliament of Canada, Sessional Paper 8555-411-980.

21 Canada, Parliament of Canada, Sessional Paper 8555-412-513.

22 House of Commons Debates, 41st Parl, 1st Sess, No 252 (21 May 2013) at 16704 (The Speaker).

23 Parliament of Canada, Standing Orders of the House of Commons, 2nd ed (Ottawa: Parliament of Canada, 2005) at Standing Order 91.1.

24 Supra note 6 at 1127.

25 Ibid.
26 Supra note 23 at Standing Order 92(4)(b).

27 See Standing Committee on Procedure and House Affairs, "Evidence", 41st Parl, 1st Sess, No 4 (20 October 2011).

28 See e.g. Standing Committee on Procedure and House Affairs, "Forty-Seventh Report", 41st Parl, 1st Sess (28 March 2013).

29 Bill C-450, An Act to amend the Marriage (Prohibited Degrees) Act in order to protect the legal definition of "marriage" by invoking section 33 of the Canadian Charter of Rights and Freedoms, 3rd Sess, 37th Parl, 2004 (reinstated from a previous session 2 February 2004).

30 Subcommittee on Private Members' Business of the Standing Committee on Procedure and House Affairs, "Minutes of Proceedings", 37th Parl, 3rd Sess, No 1 (17 February 2004).

31 House of Commons Debates, 37th Parl, 3rd Sess, No 44 (29 April 2004) at 2609-14.

32 Reference re Same-Sex Marriage, 2004 SCC 79, [2004] 3 SCR 698.

33 Standing Committee on Procedure and House Affairs, "Evidence", 37th Parl, 3rd Sess, No 6 (26 February 2004).

34 See, for example, Subcommittee on Private Members' Business of the Standing Committee on Procedure and House Affairs, "Evidence", 41st Parl, 1st Sess, No 1 (18 October 2011) at 2.

35 Subcommittee on Private Members' Business of the Standing Committee on Procedure on House Affairs, "Evidence", 41st Parl, 2nd Sess, No 8 (21 April 2015) at 2.

36 Subcommittee on Private Members' Business of the Standing Committee on Procedure and House Affairs, "Evidence", 41st Parl, 2nd Sess, No 4 (27 May 2014) at 1.

37 Supreme Court Act, RSC 1985, c S-26, s 54.

38 Rules of the Senate of Canada, r 11-18.

39 See generally Library of Parliament, "Parliament and Supreme Court of Canada Reference Cases", by Charles Feldman, Publication No. 2015-44-E (Ottawa: Library of Parliament, 12 August 2015).

40 Standing Committee on Procedure and House Affairs, "Evidence", 40th Parl, 2nd Sess, No 3 (15 June 2009).

41 The reference jurisdiction of the Supreme Court with respect to other types of legislation can only be invoked by Governor in Council. See supra note 36 at s 53.

42 The Supreme Court has not heard a private bill reference in the Charter era; however, presumably the Court would consider the Charter implications of any private bill referred to it. 
43 Library of Parliament, "Federal Back to Work Legislation: 1950 to Date, revised 1 June 2012, (Ottawa: Library of Parliament, 2012), online: <www.parl.gc.ca/Parlinfo/ compilations/HouseOfCommons/legislation/ LegislationBackToWork.aspx $>$.

44 See e.g. An Act to amend the Special War Revenue Act, SC 1941, c 27, s 29. During June 2016 consideration of legislation to permit medical assistance in dying, the Senate of Canada considered proceeding in this way. See Canada, Senate of Canada, Journals, 42nd Parl, 1st Sess, No 52 (17 June 2016).

45 See Standing Committee on Justice and Human Rights, "Minutes of Proceedings", 42nd Parl, 1st Sess, No 2 (23 February 2016).

46 Department of Justice, "Legislative Background: Medical Assistance in Dying (Bill C-14)", (Ottawa:
Department of Justice: 22 April, 2016), online: <www.justice.gc.ca/eng/rp-pr/other-autre/ad-am/ p4.html>.

47 See Canadian Civil Liberties Association, "Government Issues Lackluster Statement on Charter Impacts of Assisted Dying Bill" (22 April 2016), online: <ccla.org/government-issueslackluster-statement-on-charter-impacts-ofassisted-dying-bill/>.

48 Department of Justice, "Legislative Background: Medical Assistance in Dying (Bill C-14) Addendum", (Ottawa: Department of Justice: 13 June, 2016), online: <http://www.justice.gc.ca/ eng/rp-pr/other-autre/addend/index.html>.

49 "The right challenge", Editorial, The Globe and Mail, (29 June 2016) A10. 
